\title{
EL PRINCIPIO DEL CONSENSO DE LAS PARTES EN EL PROCESO PENAL Y ENJUICIAMIENTO JURISDICCIONAL: ACLARACIONES CONCEPTUALES NECESARIAS*
}

\author{
CARlos del Río FerretTi* ${ }^{* *}$
}

\begin{abstract}
RESUMEN: El presente estudio trata de una investigación que analiza el principio del consenso en el proceso penal y los problemas teóricos y prácticos tanto en su regulación legal como en su concreta aplicación en determinados procesos penales especiales. Se hace una examen muy preciso de determinadas prácticas dadas en la jurisprudencia penal, que surgen con la nueva regulación procesal penal, que abre espacios a lo que se conoce como negociación o transacción penal, en cuanto formas que puede adoptar el consenso de las partes dentro del proceso. Dicho fenómeno jurídico es estudiado a la luz de la vigencia normativa de determinadas garantías procesales, referidas especialmente al enjuiciamiento jurisdiccional.
\end{abstract}

Palabras clave: Proceso penal, enjuiciamiento jurisdiccional, principio de consenso y garantías procesales.

ABSTRACT: The present study treats of an investigation that analyzes the principle of the consensus in the penal process and the theoretical and practical problems both in his legal regulation and in his concrete application in certain penal special processes. There becomes one very precise examination of certain practices given in the penal jurisprudence, which arise with the new procedural penal regulation, which opens spaces to what it is known as negotiation or penal transaction, in all that forms that can adopt the consensus of the parts inside the process. The above mentioned juridical phenomenon is studied in the light of the normative force of certain procedural guarantees, recounted specially to the jurisdictional prosecution

Key words: Criminal procedure, jurisdictional prosecution, principle of consensus and procedural guarantees.

\section{INTRODUCCIÓN: EL CONSENSO DE LAS PARTES QUE INTERESA AL PROCESO JURISDICCIONAL EN SENTIDO ESTRICTO}

El principio de consenso de las partes ha venido siendo estudiado últimamente con frecuencia en la literatura procesal, tal vez por la proliferación de legislaciones que aparecen consagrando o aplicando el principio en cuestión.

\footnotetext{
* El presente estudio es resultado del proyecto DGIP 2006-2007 (Universidad Católica del Norte) concedido al autor.

** Doctor en Derecho por la Universidad de Valencia y profesor de Derecho procesal de la Universidad Católica del Norte.
} 
En efecto, solemos encontrar variadas manifestaciones del consenso de partes en las legislaciones procesales penales modernas, que reconocen diversas formas y medios por las cuales las partes pueden acordar o pactar la celebración y/o contenido de un determinado acto procesal, que producirá específicos efectos legalmente sancionados.

Sin embargo, las diversas formas de consenso no tienen una misma naturaleza. Algunas veces el consenso se produce respecto de un objeto muy acotado, como acontece con las convenciones probatorias respecto del thema probandum y con un efecto jurídico determinado de manera específica, que en este caso incide sobre las aportaciones probatorias y la amplitud del objeto de debate probatorio.

Otras veces se manifestará en relación con la promoción de formas no jurisdiccionales ni punitivas de resolución del asunto penal, dando lugar a las denominadas soluciones o "salidas alternativas" al proceso jurisdiccional, como son en el sistema chileno la suspensión condicional y el acuerdo reparatorio.

En las formas de solución alternativa es claro que el consenso de las partes es un presupuesto necesario de procedencia de las mismas. Con todo, no es este consenso el que importa al proceso penal en sentido estricto (como instituto jurídico por el cual se realiza la función jurisdiccional) ni al enjuiciamiento jurisdiccional, pues se trata de un tipo de consenso que justamente permite de manera excepcional "salirse" del mismo proceso jurisdiccional para buscar una forma no jurisdiccional y no punitiva de resolución del asunto penal ${ }^{1}$.

En este caso nos hallamos ante un consenso que a la vez es expresión del principio de oportunidad, pero solo entendido este como facultad para no ejercer o abandonar la acción penal (que es la única forma de oportunidad que de manera reglada se admite en Chile).

\section{EL CONSENSO INCRIMINATORIO O COLABORADOR CON LA PERSECUCIÓN CRIMINAL}

$\mathrm{Al}$ proceso jurisdiccional le interesa un tipo de consenso distinto, que es aquel que se produce dentro o en el proceso penal en sentido estricto, que no implica "salirse" del proceso para no ejercer o abandonar la acción penal y permitir una solución no jurisdiccional (no punitiva), sino que justamente supone o importa la misma existencia del proceso jurisdiccional y la solución del asunto penal a través de la aplicación del ius puniendi. En otras palabras, nuestro objeto de estudio es el consenso de las partes en el proceso penal que se expresa bajo fórmulas, acordadas por el acusador y el acusado, de autoincriminación o de colaboración de este último con la más expedita persecución criminal.

El principio de consenso en el proceso penal implica que las partes puedan llegar a un acuerdo sobre la forma procedimental a que se someterá el asunto penal o, incluso, respecto del contenido fáctico y jurídico-penal del mismo asunto.

\footnotetext{
${ }^{1}$ La doctrina chilena en general parte de la aceptación de esta idea o presupuesto, aunque no siempre lo exprese. HORVITZ (2002) pp. 448-452 y 552-579; CHAHUÁN (2002) pp. 247-256.
} 
En este sentido, las voluntades de las partes pueden ser manifestadas de maneras separadas y unilateralmente, en la cual la acusación deduce una pretensión y pide la aplicación de un procedimiento determinado y el acusador acepta por su parte de manera separada y unilateralmente esa petición, pero cabe también (y quizás con mucha más frecuencia) que el consenso se dé como consecuencia o resultado de unas tratativas previas tendientes a producirlo, en cuyo caso nos hallamos frente a un consenso de carácter transaccional.

Sin embargo, más allá de esta distinción inicial, que suele tener trascendencia vinculada a los incentivos lícitos para llegar al acuerdo, todavía tiene más importancia distinguir tipos de consensos atendiendo al objeto o materia respecto de la cual versa el acuerdo. En efecto, desde esta perspectiva hallaremos dos tipos bien diferenciados.

\section{EL CONSENSO SOBRE EL RITO PROCEDIMENTAL}

De una parte, nos encontraremos con el consenso de las partes que consiste en la disposición del acusado de su derecho de defensa en un juicio oral ordinario ${ }^{2}$, por el cual acepta una forma abreviada o simplificada de juicio, y a la que el legislador le asigna un efecto jurídico-procesal que consistirá en la producción de un resultado alterador del procedimiento, haciéndolo más breve o suprimiendo una etapa procesal o provocando una deflación en el debate del juicio, a través, por ejemplo, de la supresión de la práctica de la prueba.

En Derecho comparado esta manifestación del consenso de las partes no plantea muchas dudas sobre su legitimidad, salvo en aquel punto que se refiere a la libertad y voluntariedad con que se manifiesta la aceptación del acusado, habida cuenta la práctica de utilizar ciertos estímulos ilegales. De esta manera se encontrarán manifestaciones bastante consolidadas en los países europeos, como España, Portugal o Italia. En este último a esta forma de consenso se le conocía con la expresiva denominación de pattegiamento sul rito ${ }^{3}$, que se usaba con la finalidad de poner de relieve que el consenso de las partes (del acusado) solo producía un efecto simplificador (alterador y deflativo) del proceso, nunca sobre el mérito.

\section{EL CONSENSO SOBRE EL MÉRITO DEL PROCESO: FÁCTICO Y JURÍDICO}

Cosa muy distinta a la precedente es aquel consenso de las partes que ya no solo tiene por objeto el rito procedimental (la abreviación o la supresión de etapas procedimentales o la deflación del debate del juicio), sino también la disposición sobre el objeto del proceso y de ese modo además sobre la ley penal sustantiva. En este caso el consenso se producirá sobre el mérito fáctico y jurídico de la pretensión procesal punitiva y su fin, reconocido legalmente, será determinar el contenido de la decisión jurisdiccional que

\footnotetext{
${ }^{2}$ Conviene resaltar que no se trata tanto de una disposición del derecho de defensa, sino más bien de la disposición del derecho a defenderse en un juicio oral, pues la aceptación del acusado no supone aceptación de la pretensión punitiva y porque además resulta totalmente compatible con una variada gama de estrategias y alegaciones de defensa. VIVES (1985) pp. 114-116; MORENO (1997) pp. 359-364; De DiegO DíEZ (1997) pp. 188-195.

3 Orlandi (2003) pp. 576 y ss. También Ferrajoli (1995) pp. 746-750.
} 
justamente por ello deja de ser jurisdiccional, pasando a constituir un acto judicial de homologación ${ }^{4}$.

Para valorar esta forma de aplicación del Derecho penal sustantivo (del ius puniendi) conviene tener en cuenta afirmaciones como las de Orlandi ${ }^{5}$, quien ha establecido que todo procedimiento basado en el consenso incide sobre determinados derechos constitucionales, tales como la igualdad y la defensa del imputado, o el derecho al juez natural, o incluso la presunción de inocencia. Por dicha razón compartimos con el autor la consideración de que la limitación o afectación de estos derechos debe venir expresamente autorizada por la ley y además debe aparecer que esa limitación o afectación es razonable a la luz de un adecuado balance entre eficiencia del sistema procesal con una aceptable protección de derechos individuales.

El sistema chileno reconoce sin duda el principio de consenso en el proceso penal. El problema no parece ser este sino más bien la precisión normativa, ya que la regulación es escasa, lagunar, ambigua, e, incluso, a veces, incoherente.

Con la lectura y estudio del sistema chileno se llega al convencimiento de que el legislador no acababa de tener en claro cuál de los dos sistemas de consenso se estaba consagrando efectivamente y qué problemas concretos podían suscitarse. Por dicho motivo quizás (casi) no se observan normas claras que atiendan a la resolución de estos. Si no se tuvo claridad de cuáles podían ser los problemas jurídicos, menos posibilidades había de establecer mecanismos procesales de prevención o de control sobre dichos aspectos. La muestra más palmaria de lo que se viene diciendo nos la da la praxis de estos años de reforma, donde se presentan prácticas inadmisibles en nuestro sistema y que, sin embargo, el mismo sistema no es capaz de prevenir o de evitar. Así, por ejemplo, el caso de fiscales que alegan hechos inexistentes o recortados o hacen calificaciones jurídicas groseramente incorrectas, con las cuales quieren persuadir o compensar las aceptaciones (confesiones) de los acusados: ¿libertad de la aceptación, pero con coacción psicológica?, ¿principio de legalidad procesal y sustantiva, pero alterado de manera ilegal?, ¿igualdad ante (qué) ley penal? Y en este contexto de ¿qué manera se puede entender respetada la presunción de inocencia si lo que se busca es forzar un determinado contenido incriminatorio?

Ante estos problemas, justo es reconocerlo, la Fiscalía Nacional se ha pronunciado censurando y prohibiendo a los fiscales ciertas prácticas, pero sin mucha contundencia y poca eficacia ${ }^{6}$.

\section{CONSENSO DE LAS PARTES, PRINCIPIOS DE LEGALIDAD Y OPORTUNIDAD}

Suele hacerse una asociación ideológica inmediata entre el principio del consenso con el de oportunidad, como si el primero importara necesariamente la existencia del segundo. Estimamos que esta asociación es inexacta fundamentalmente por dos razones.

\footnotetext{
${ }^{4}$ Expone con claridad esta cuestión FerrajOLI (1995) pp. 744-750. También GASCÓN (1999) pp. 125 y ss.

5 ORLANDi (2003) pp. 553-554.

${ }^{6}$ Así se puede observar en Oficio de la Fiscalía Nacional No 401, de 20 de agosto de 2003, y Oficio de la Fiscalía Nacional No 724, de 12 de diciembre de 2005.
} 
La primera es muy básica: aquella va a depender de qué entendamos por principio de oportunidad; de su concepto más o menos amplio depende la veracidad de la implicación que a menudo se establece entre consenso y oportunidad.

La segunda razón es que aun cuando se mantenga un concepto amplio de principio de oportunidad, no siempre se podrá sostener que el consenso de las partes imponga como consecuencia la necesidad de que haya o se dé espacio o reconocimiento a la oportunidad con menoscabo del principio de legalidad.

La oportunidad procesal puede ser entendida de manera restringida, refiriéndola fundamentalmente al reconocimiento de un poder del órgano de acusación pública para prescindir del deber de ejercer la acción penal (y acusar) cuando toma conocimiento de la probable comisión de un hecho delictivo o para abandonar la acción penal cuando ya ha sido ejercida y subsistan los presupuestos que han justificado dicho ejercicio ${ }^{7,8}$.

Este concepto de oportunidad no llega a vincularse con el principio de consenso de las partes, el cual opera sobre la forma procedimental o la pretensión procesal punitiva, pues, tal cual hemos dicho, este supone necesariamente el ejercicio de la acción y su sostenimiento, y no su no ejercicio o abandono ${ }^{9}$. En este caso la oportunidad no representa más que el poder negativo del MP de no ejercer la acción penal o de abandonarla, sin referencia alguna a la forma procedimental o al contenido de la pretensión procesal penal.

Hay, en cambio, una segunda manera de entender el principio de oportunidad, que podría definirse como más amplio y extensivo. En esa amplitud se comprende en él toda forma o manifestación de no legalidad, ya no solo referido al no ejercicio de la acción penal, sino también respecto al procedimiento de sustanciación del asunto penal, tanto como al objeto procesal y penal sustantivo.

De la Oliva, con mucha precisión, y en el sentido anotado, ha dicho que ampliamente considerado el principio de oportunidad sería "aquél en cuya virtud el ius puniendi estatal no habría de ser declarado o establecido, siempre según parámetros legales, en todo caso que concurriesen sus presupuestos, sino que estaría sometido al poder atribuido al Ministerio Fiscal (u órgano oficial similar) para disponer, bajo condiciones precisamente especificadas en la ley o con amplio arbitrio, del ejercicio y del modo de ejercicio

\footnotetext{
7 GiMeno (1997) p. 64.

8 Dentro de esta forma de concebir la oportunidad, en el caso chileno se articulan tres modalidades procesales distintas. Primero, la oportunidad del art. 170, que regula en sentido estricto el poder de no ejercer o abandonar la acción penal. Segundo, la regulación de la denominada suspensión condicional, por la cual se regula un mecanismo procesal de suspensión provisoria del procedimiento bajo determinadas condiciones y que en definitiva puede conducir al abandono definitivo de la acción penal. Tercero, el denominado acuerdo reparatorio, que también supone el abandono de la acción penal.

${ }^{9}$ Es evidente que nuestro estudio se refiere al consenso de las partes que tiene un signo autoincriminatorio o que facilita la persecución o incriminación penal, de modo que dejamos fuera de nuestro análisis otras manifestaciones del consenso de partes, como las que se dan en la suspensión condicional y en el acuerdo reparatorio, ya que a nuestro entender obedecen a un fenómeno jurídico distinto, que entronca más bien con la introducción de formas no jurisdiccionales y no punitivas de solución del asunto penal. Desde luego, también a estas fórmulas consensuadas de solución del asunto jurídico-penal se les atribuyen graves problemas de legitimidad jurídica.
} 
de la acción penal, independientemente de que se hubiese acreditado la existencia de un hecho de apariencia punible y de que apareciesen unos presuntos autores del mismo"10.

Y a continuación concluye: "El principio de oportunidad entraña, pues, disponibilidad sobre el objeto del proceso y sobre este mismo (...)”.

"Quiérese decir que, en mi opinión, se está ante un sistema que admite el principio de oportunidad si, con independencia de la vinculación del Tribunal al comportamiento de los acusadores, le es lícito al Fiscal no perseguir todos los hechos delictivos que conoce y si puede configurarlos prescindiendo de circunstancias fácticas relevantes jurídico-penalmente según las normas objetivas y si le cabe no atenerse a la legalidad para valorar jurídicamente esos hechos y solicitar la pena"11, 12 .

Se trata de una conceptualización del principio de oportunidad completa, dentro de la cual hallan cabida todas las posibilidades o manifestaciones de lo que se puede etiquetar como expresión del principio de oportunidad.

Solo con esta amplitud se advertirá que se opone en términos completos a la legalidad, tanto en su aspecto procesal cuanto sustantivo.

La legalidad posee en efecto dos facetas bien claras y diferenciadas ${ }^{13}$. La procesal se expresa, en primer lugar, en el sometimiento a regulación legal de las potestades del MP, que justamente en el ejercicio de las mismas queda sometido al principio de legalidad, debiendo ejercerlas solo y cada vez que tome conocimiento de un hecho que reviste caracteres de delito (arts. 77 y 166 CPP), lo que se expresará en el principio de legalidad que rige los poderes de investigación del MP y en el principio de necesidad que gobierna el ejercicio de la acción penal.

También resulta ser ejemplo claro de legalidad procesal la regulación legal de los procedimientos y las fases procesales que se han de aplicar en cada tipo de asunto penal, debiendo necesariamente someterse las partes a dichos procedimientos y fases procesales, con plena vigencia normativa de las garantías procesales.

Por otro lado, el principio de legalidad en su vertiente penal sustantiva ha de significar para el MP que este no puede acusar sino por los hechos y ajustando su acusación, su calificación jurídica y petición de pena, a la ley penal. Esto no es más que una natural consecuencia de que en materia penal rija sin excepciones el principio de reserva legal, con lo cual los hechos delictivos están precisamente descritos en la ley, en la ley está también la o las figuras delictivas en las cuales se han de subsumir cada una de esas descripciones fáctico-típicas y, por último, en la misma se señalan las consecuencias jurídicas que produce la comisión de esos hechos delictivos ${ }^{14}$.

\footnotetext{
10 De la Oliva Santos (1992) pp. 9882-9883.

11 De la Oliva Santos (1992) p. 9883.

12 Nótese que es esto justamente lo que ocurre en el sistema estadounidense con la plea bargaining. LAFAVE (1992) pp. 926 y ss.; HEUMANN (1978) pp. 92 y ss., y especialmente pp. 116 y ss.; PIZZI (2004) pp. 102104 y 207-216; RodríGUEz GARCÍA (1997) pp. 65-67.

13 Esta diferenciación la realizan penalistas y procesalistas. BUSTOS RAMíREZ (1994) pp. 131-151; DE Diego DíEZ (1997) pp. 202-217.

14 De la Oliva Santos (1992) p. 9877; Vives Antón (1985) pp. 108-110; Montero Aroca (1997) pp. 15-23 y 77-79; DE DIEGO DÍEZ (1997) pp. 202 y ss.
} 
La oportunidad en este aspecto ya no se limita a contener un poder negativo de no ejercer acción penal, ahora se extiende como una excepción al deber de sometimiento a la legalidad penal sustantiva: puede el MP prescindir de hechos jurídicos relevantes o introducir hechos no acreditados o pactar una calificación jurídica improcedente.

La regulación chilena del consenso de las partes en el proceso penal, ¿de qué manera toca o se vincula con la vigencia de la legalidad y de la oportunidad tal como han sido expuestas? La respuesta a esta cuestión requiere de varios matices.

Primeramente es menester volver a la distinción de tipos de consensos. Así, el que se produce sobre el rito procedimental y que proyecta sus efectos solo a este aspecto, no afecta ni puede afectar al mérito procesal, en consecuencia deberíamos convenir de que no llegará a comprometer la legalidad penal sustantiva. Este tipo de consenso significa entonces una forma limitada de aplicación del principio de oportunidad, en el sentido preciso que con el acuerdo o aceptación del acusado sobre la conveniencia de someter el asunto penal a un procedimiento especial que simplifica o abrevia el proceso, sea suprimiendo o acotando el debate del juicio (procedimiento deflativos del debate), solo implica apartarse de la legalidad procesal en cuanto las partes deciden someter el asunto a un "procedimiento alternativo" que no es el inicialmente previsto por el legislador, pero en todo lo demás no cesa en ningún punto la legalidad. No cesa la necesidad de acusar y de sostener la acusación ante el hecho delictivo, ni mucho menos cesa el deber de formular la pretensión procesal por el hecho que efectivamente existe y por la calificación jurídica y pena que corresponde conforme a la ley penal, no pudiendo disponer el acusador de los hechos con relevancia jurídico-penal ni tampoco de las figuras delictivas y de las penas.

Distinta es la situación del consenso de las partes cuando este tiene por objeto el mérito del proceso y en consecuencia las partes están constitucional y legalmente autorizadas para transar o pactar sobre el mismo (que no es el caso chileno), acordando un contenido fáctico con independencia de la realidad de los mismos, y/o pactando sobre los hechos calificaciones jurídicas y peticiones de penas que no se corresponden necesariamente con las legalmente previstas. Esta forma de consenso (sobre el mérito) sí que importa, a diferencia de la anterior, una importante y amplia inaplicación de la legalidad, ahora no solo procesal, sino también sustantiva. Ejemplo paradigmático (bastante manido) es el de la plea bargaining del sistema estadounidense, donde se tolera como práctica admisible ${ }^{15}$.

La cuestión estriba en determinar técnicamente qué es lo que sucede, normativamente hablando, en el sistema chileno con el consenso de las partes. Cómo se regula y qué es lo constitucional y legalmente admisible ${ }^{16}$. Las dudas fundamentales pueden venir por las regulaciones del procedimiento abreviado, del "reconocimiento de responsabilidad" del art. 395 (dentro del procedimiento simplificado) y del procedimiento monitorio.

15 Lafave e Israel (1992) pp. 926 y ss.; Heumann (1978) pp. 92 y ss., y pp. 116 y ss.; Pizzi (2004) pp. 102-104 y 207-212; RODRíGUEZ GARCía (1997) pp. 65-67.

${ }^{16}$ A este respecto ORLANDI (2003) pp. 553-554. 
Esencialmente sostenemos que dentro del ordenamiento chileno no cabe admitir sino una aplicación del principio del consenso de las partes respecto del rito procedimental, pero no sobre el mérito procesal, salvo de manera restringidísima en cuanto haya reconocimiento legal de efectos limitadores del marco punitivo. No hay base constitucional ni legal para afirmar otra cosa. Lo contrario supondría destruir los fundamentos del Derecho penal moderno, especialmente por el problema que presentan los procesos penales en que se admite el consenso sobre el mérito, que suponen el pacto sobre la aplicación de una pena sin juicio jurisdiccional, ya que con ello se corre el riesgo cierto de establecer un Derecho penal que prescinda del principio de culpabilidad, es decir, de consagrar un sistema punitivo que aplica penas sin la previa verificación de participación culpable 17,18 .

Solo comprendiendo los alcances de lo establecido precedentemente se puede hablar con justeza debida de la transacción o negociación penal. En este sentido, no incumbe tanto si el consenso ha sido el fruto de tratativas previas en la que se llega a un acuerdo transaccional, como determinar que en nuestro sistema esto hallará un límite insuperable: el acusador no puede disponer de la norma penal, haciendo calificaciones mañosas o quitando o introduciendo hechos con relevancia penal.

\section{LOS EFECTOS JURÍDICOS DEL CONSENSO EN EL SISTEMA CHILENO}

Más allá de esta diferenciación, sin embargo, estos procesos que admiten, dentro de ciertos márgenes, el consenso, plantean graves problemas técnicos al régimen procesal penal y que suelen tocar a la esencia del mismo sistema jurisdiccional.

Ya hemos dicho que en primer lugar está la determinación de la materia sobre la que puede haber consenso (¿solo sobre el rito procesal o también sobre los hechos, sobre la calificación jurídica y la pena?). En segundo lugar, sobre qué base se pueden producir esos consensos (premios o incentivos legales y legítimos). Y, por último, lo más importante de todo y objeto específico de nuestro estudio, cuáles son los efectos jurídicos del consenso.

17 La doctrina más autorizada apunta de manera invariable a esta conclusión. MONTERO AROCA (1997) pp. 77 y ss.; y FERRAJOLI (1995) pp. 21-957.

PIZZI (2004) pp. 212-216, pone en evidencia la manera en que influye un sistema de justicia criminal basado en las negociaciones extraprocesales, como el estadounidense, en el desarrollo de un sistema penal (de castigo) diferenciado, con dos tipos de normas penales. Una norma penal previamente establecida y sancionada "legalmente" y otra que es la que se acaba pactando caso a caso y que difiere sustancialmente de la que debería haberse aplicado en realidad. La norma penal legalmente prevista solo se aplica al acusado que se resiste a confesar y opera en definitiva cual si fuera un castigo adicional.

Otro fenómeno que se pone de relieve por Pizzi es aquel que consiste en que ante la grave diferencia que se produce entre la norma penal sancionada y aquella que se termina aplicando en la realidad y que resulta a raíz de la negociación mutada y atenuada, se produce una fuerte presión social por elevar las previsiones penales legales a límites desorbitantes, con el fin de dar un piso de negociación a la fiscalía muy alto, para que de ahí negocie hacia abajo.

Esta claro que un Ordenamiento Jurídico que se tome en serio el Derecho penal y sus conquistas no puede admitir este tipo de situaciones. Se volverá sobre este punto más adelante.

18 Nuestra tesis doctoral: Del Río FERRETI (2009) pp. 422-426, en la que se sostiene esta opinión sobre la base de posiciones más generales de RoXIN (2000) pp. 100-102; y SCHÜNEMANN (2005) pp. 99-109. 
Sobre el último punto vamos a dirigir nuestra atención (los efectos jurídicos del consenso), pero para hacerlo adecuadamente debemos analizarlo desde una perspectiva integral, desde donde cuentan y se entrelazan los otros dos aspectos consignados: sobre qué (materia u objeto) y cómo se llega al consenso (los incentivos).

Cuando el legislador debe disciplinar los efectos procesales del consenso tiene dos posibilidades. Una primera que es asignarle a ese consenso un ámbito y una consecuencia jurídica fundamentalmente limitada al rito procedimental, a través de su abreviación o supresión de alguna etapa procedimental, con el fin de permitir que el proceso pase directamente a la fase de enjuiciamiento y de esa manera conseguir celeridad y racionalización de medios. La segunda, en cambio, se trata de asignarle un ámbito sobre el mérito procesal y reconocerle ciertos efectos jurídicos sobre el mismo enjuiciamiento, y que consiste en otorgarle al consenso una consecuencia determinadora del contenido de la resolución jurisdiccional, de manera que el juzgador ya no enjuicia libremente sino que su pronunciamiento viene total o parcialmente determinado por el acto de parte.

En este caso se podría decir que el acto de consenso reviste el carácter de acto de causación, en la teoría procesal de Goldschmidt ${ }^{19}$. Como se sabe, los actos de las partes se clasifican en actos de obtención, que son aquellos dirigidos a obtener del juez una resolución favorable o a proporcionarle los elementos de juicio para que la dicte fundadamente, y en actos de causación, que son aquellos que producen por sí mismo una determinada situación jurídica, o que si requieren de una resolución judicial para producir la situación jurídica pretendida, van dirigidos a determinar su contenido. Sin embargo, la aplicación frontal o solapada de esta última categoría jurídica en el proceso penal presenta graves y profundas objeciones técnicas en un sistema penal de legalidad y garantía, como pretende ser el chileno ${ }^{20}$.

A este respecto, la regulación del CPP es técnicamente deficiente, pues es escasa y confusa, y en consecuencia la reglamentación específica del Código alcanza para bien poco desde el punto de vista normativo. Con todo, creemos que haciendo una interpretación del Código en el contexto del Ordenamiento chileno en su totalidad se ha de arribar a una respuesta normativa clara y rotunda.

Nuestra lectura, cabe reconocerlo, es notoriamente garantista y jurisdiccionalista y se basa en la doctrina sentada por autores como Montero Aroca u Ortells Ramos (en España), Ferrajoli (en Italia) o Schünemann (en Alemania).

Los presupuestos en que se apoya el presente estudio son, por una parte, la general intangibilidad de la legalidad penal y el carácter necesariamente jurisdiccional de la aplicación de esa legalidad penal (que proclama el art. $1 \mathrm{CPP}$ ), y, por otra, la vigencia irrestricta de la presunción de inocencia y su relación con la necesaria carga de la prueba del acusador.

19 Goldschimdt (1935) p. 63. También en De Diego Díez (1997) pp. 138-139.

20 Desarrollamos en detalle varios aspectos vinculados a esta materia en DEL Río FERRETI (2006) pp. 445 y ss. 


\section{Problemas mal Resueltos en la práCtica y EN El CPP}

Al estudiar la jurisprudencia producida durante este breve período de aplicación del nuevo sistema de justicia penal advertimos que se ha incurrido en prácticas reprochables $^{21}$. Tal vez dichas prácticas deban su causa a una cierta ambigüedad de la norma en la regulación del consenso, la que ha sido aprovechada para introducir mayores espacios de acuerdo penal de los que en principio serían admisibles.

En cuanto al aprovechamiento del procedimiento abreviado para producir o incentivar una negociación (y lo mismo en el reconocimiento de responsabilidad del art. $395 \mathrm{CPP}$ ), se ha usado especialmente (pero no únicamente) de la oportunidad que tienen las partes de acordar el procedimiento abreviado en la audiencia de preparación del juicio oral. En efecto, tras la acusación inicial en la que se puede presentar una petición de procedimiento abreviado por escrito, se permite que en la audiencia de preparación se intente por segunda vez, o por primera, un acuerdo entra las partes que dé lugar al procedimiento abreviado, para lo cual se puede modificar la acusación y la petición de pena (art. 407 del CPP y lo mismo ahora en el art. 395 CPP).

No cabe duda que esta norma tiene un fin de incentivo de la negociación. Si no, entonces, cómo se justifica la autorización de la modificación de la calificación y de la pena sin que se haya producido ningún cambio en los elementos de juicio en que se basan. El problema en realidad no consiste en establecer si las partes pueden negociar, sino más bien en determinar cuánto margen a la negociación se puede autorizar al amparo de esta norma.

Conviene poner de relieve que las prácticas que vamos a analizar poseen dos aspectos vinculados entre sí y que por eso tratamos conjuntamente. Por una parte buscan provocar y compensar de manera ilícita la confesión del acusado a través de rebajas de la pretensión punitiva al margen de la ley penal y, de otra, persiguen "forzar" al juez de garantía a que recoja en sentencia el contenido intencionadamente equivocado de la acusación, privándole en la práctica de sus poderes de enjuiciamiento. Este segundo aspecto, que es el de la eficacia del consenso sobre el contenido de la resolución del asunto, es fundamental para que el primer aspecto sea posible, es decir, para que las rebajas ilegales sean efectivamente un incentivo y compensación de la confesión.

Ahora trataremos de demostrar lo que hemos venido sosteniendo, en el sentido que la negociación aceptable en el marco del procedimiento abreviado debe respetar ciertos límites que derivan del sistema legal y del proceso penal de garantías y que sus efectos no pueden afectar jamás los poderes de enjuiciamiento que aseguran la garantía jurisdiccional en la aplicación del Derecho penal. Desde estos puntos de vistas creemos que hay cuatro razones que limitan la negociación. En primer lugar, el respeto a los principios de legalidad y objetividad que rigen las potestades y actuaciones del MP. En segundo lugar, la vigencia del principio de legalidad penal sustantivo (nulla poena et

21 Como hemos dicho en una nota supra, hay que tener en cuenta determinadas prácticas dadas en el sistema estadounidense de negociación penal, a través de las cuales se maneja el contenido de los cargos de manera bastante discrecional. LAFAVE E ISRAEL (1992) pp. 898 y ss.; HEUMANN (1978) pp. 92 y ss., y especialmente pp. 116 y ss.; PIZZI (2004) pp. 102-104 y 207-212; CABEZUdo RodrígUEZ (1996) pp. 103-112; Rodríguez GARCÍA (1997) pp. 65-67; SCHÜNEMANN (2005) pp. 99-109. 
nullum crimen sine lege y nulla poena sine crimine et sine culpa $)^{22}$. En tercer lugar, la exclusividad de las potestades jurisdiccionales en la aplicación del Derecho penal. Y en cuarto lugar, la vigencia de la presunción de inocencia y la carga (formal) de la prueba sobre la acusación ${ }^{23,24}$.

La negociación no puede infringir estos límites. Así, la acusación pública (el MP) debe ser respetuosa de la legalidad y de la objetividad en el ejercicio de sus potestades, es decir, cuando acusa le debe animar la correcta aplicación de la ley, y no su incorrecta aplicación como medio eficaz para provocar la confesión. Además, la negociación de partes -y sobre todo la acusación pública- debe respetar la legalidad penal sustantiva que establece cuáles precisos hechos lesivos constituyen cuáles precisos delitos, a los que se les atribuyen unas determinadas y proporcionadas consecuencias penales, cuestión que impediría hacer calificaciones manifiestamente incorrectas. Por otra parte, la negociación debe ser respetuosa de la exclusividad de las potestades jurisdiccionales de los tribunales de justicia en la aplicación del Derecho penal, de modo tal que ella no puede implicar jamás la imposición no jurisdiccional de penas o el forzamiento del juez a sancionar un acuerdo punitivo negociado. Y en último término, la negociación no puede infringir la presunción de inocencia mediante su conversión en un mecanismo de provocación de confesiones que exonere a la acusación de aportar genuinos elementos de convicción.

Desde estas perspectivas, cabe denunciar las prácticas del MP que han sido toleradas y consentidas por los jueces, tendientes a provocar y estimular la negociación y a determinar el contenido de la sentencia (de manera ilícita), y que nos parecen del todo censurables $^{25}$. Estas son las siguientes:

a) La manipulación fáctica del hecho punible o de alguna circunstancia fáctica con el fin de dar lugar a una calificación jurídica menos grave. Estos casos en la jurisprudencia se han dado con frecuencia. Por ejemplo, en SJG de Loncoche, de 22 de abril de 2002, rit 764-2001 se trataba de una acusación por hechos que evidentemente constituían un robo en bienes nacionales de uso, y en la segunda acusación se recortaron para dar lugar a un hurto. Se omitió la circunstancia de haberse roto los cristales del vehículo para acceder a su interior. Otro caso, en sentencia del Juzgado Mixto de Taltal, de 23 de marzo de 2002, rit 109-2002, se trataba de un robo con violencia, pero en la segunda acusación se omite la circunstancia de la violencia para dar lugar al robo por sorpresa. Y como estas otras tantas situaciones que se vienen produciendo a diario.

b) La incorrecta modificación de la calificación jurídica de la acusación sin hacer ningún ajuste a los hechos. Situaciones de este tipo se han venido dando de manera muy

\footnotetext{
22 Ferrajoli (1995) p. 35.

23 Repetimos aquí la advertencia y explicación que hemos dado para justificar el uso del concepto de la carga formal de la prueba en el caso del proceso penal chileno.

${ }^{24}$ Una crítica muy certera de ciertas prácticas sobre negociación penal desde la perspectiva de las garantías procesales en SCHÜNEMANN (2005) pp. 99-109.

25 Cabe recordar las graves denuncias que hace PIZZI (2004) pp. 102-104 y 207-212, contra el sistema estadounidense por la forma en que se consiguen las confesiones de los acusados y la poca voluntad del sistema -específicamente del juez- de realizar un auténtico control de legitimidad de los pactos penales.
} 
frecuente y los ejemplos abundan. Un caso es la de la SJG de Linares, de 23 de febrero de 2003, rit 1845-2002, en la cual un hecho que se califica inicialmente de robo con fuerza acaba siendo recalificado de receptación, cuando parece estar perfectamente demostrado el primer tipo. La situación es grosera pues el cambio de calificación jurídica sin ajustes de hechos es incomprensible, ya que justamente el robo y la receptación son tipos que desde el punto de vista procesal se basan en hechos distintos ${ }^{26}$.

Otro caso muy descriptivo de estas situaciones es el que se da en la SJG de Temuco, de 18 de junio de 2002, rit 3615-2001. Se acusa por robo en lugar habitado, pues se produjo en el patio de una casa. La doctrina y la jurisprudencia es unánime en considerar el patio de la casa un lugar habitado. Con todo, en el cambio de calificación se acusa por robo en lugar no habitado.

Últimamente se puede mencionar el caso de la SJG de Santiago (15\%), de 10 de mayo de 2007, rit 4235-2006, en el cual se registra la situación siguiente: ante un robo con fuerza en lugar habitado se acaba modificando la acusación haciendo una calificación claramente incorrecta de robo en lugar no habitado. Nótese que los rangos de pena del robo en lugar habitado no permiten la aplicación del procedimiento abreviado. Era evidente que la calificación correcta era esta y no la de robo en lugar no habitado, pues se trataba del robo en el domicilio de una familia, en el cual esta mantenía un típico almacén de barrio dentro de la misma morada que ocupaba para vivir.

Pero todavía más, en este caso si se lee el acta de la audiencia de preparación del juicio oral se observará que el MP hizo de todo para provocar (rectius: forzar) el procedimiento abreviado y obtener el consentimiento del acusado. Primero quiso inventarse una atenuante, la de reparar con celo el mal causado, aparte de la calificación incorrecta del robo con el fin de ofrecer una rebaja importante de pena. El juez ante tan evidente ilegalidad se opuso al procedimiento abreviado. Tras eso, con el propósito de convencerlo volvió a corregir la acusación a robo en lugar habitado, pero manteniendo la atenuante inventada. El juez se volvió a oponer. La tercera intentona fue la vencida, para lo cual se utilizó la estrategia inversa de quitar la atenuante inventada, pero haciendo en cambio la calificación jurídica errada de robo en lugar no habitado, que fue en definitiva el contenido de la acusación.

c) La alegación de hechos atenuantes (inexistentes) o el abandono de hechos agravantes (existentes). Es la tercera "técnica" usada por los acusadores para provocar la aceptación del imputado. Un ejemplo claro en que se abandonan las circunstancias agravantes es el que se da en SJG de Loncoche, de 11 de septiembre de 2001, rit 77 2001, en la cual el fiscal aparece desistiéndose de la circunstancia de la reincidencia y de la premeditación conocida, sin que mediara ninguna razón fáctica o jurídica en ese acto de abandono. También los fiscales suelen incurrir en la alegación repentina de lo contrario, de una atenuante, que no había sido alegada con anterioridad y que no parece estar justificada en absoluto: así aconteció en SJG de Taltal, de 23 de febrero de 2002, rit 75-2001.

${ }^{26}$ La estructura fáctico-típica del robo y de la receptación son esencialmente distintas, y no cabe duda que no se puede pasar de una figura a otra sin romper con el deber de correlación (de congruencia). 
Como se ve, hemos señalado las principales prácticas dadas en el foro, y que, según anunciamos, estimamos jurídicamente reprochables. A continuación corresponde expresar las consideraciones jurídicas fundamentales en que se basa nuestra posición.

\section{LEGALIDAD Y OBJETIVIDAD COMO PRINCIPIOS QUE RIGEN LAS POTESTADES Y ACTUACIONES DEL MP}

Nos interesa analizar la atribución de potestades al MP como institución que se encarga de llevar adelante la persecución penal pública y de instar por la aplicación del ius puniendi ante los tribunales de justicia. En este sentido, esta institución tiene tantas potestades para cumplir con dichas funciones cuantas la ley le atribuya, y además ha de ejercerlas con pleno sometimiento a la misma. En consecuencia, sus márgenes de discrecionalidad existen en la medida que previamente hayan sido entregados y regulados por ley expresa. Cualquier otra cosa es ilegítima arbitrariedad e ilegalidad ${ }^{27}$, pues el Ordenamiento chileno somete al MP al principio de legalidad en toda su amplitud (art. 83 de la CPR, arts. 1 y 3 de la LOCMP, arts. 77 y 166 del CPP) ${ }^{28}$.

El principio de objetividad, a su turno, se establece como la consecuencia del de legalidad. La objetividad impone al MP el deber de actuar en el ejercicio de sus funciones bajo "un criterio objetivo, velando únicamente por la correcta aplicación de la ley" (así lo establece el art. 3 de la LOCMP. También el art. 1 de la LOCMP, el art. 83 de la CPR y art. 77 del CPP) ${ }^{29}$. De este principio se deriva que el MP deberá investigar "con igual celo no solo los hechos y circunstancias que funden o agraven la responsabilidad penal del imputado, sino también los que le eximan de ella, la extingan o la atenúen" (art. 3 LOCMP. También en términos parecidos el art. 1 de la misma ley y art. 83 de la CPR) ${ }^{30}$.

Pero más importante aún es la segunda derivación del principio de objetividad, tocante a la función acusadora del MP. En virtud de este principio los fiscales no pueden hacer o dejar de hacer sino aquello que la recta interpretación de la ley ordena o prohíbe. Es decir, el MP si bien es la parte acusadora en el proceso penal y "pretende" la condena del acusado, no puede pretenderla al margen de la correcta aplicación de la ley penal. Por esta razón, el fiscal no puede hacer intencionadamente calificaciones incorrectas que se aparten de la ley ni formular acusación por hechos retocados, para conseguir una confesión ${ }^{31}$.

\footnotetext{
27 Por tal motivo rechazamos rotundamente ciertas posiciones en la doctrina chilena que pretenden introducir un sistema discrecional bastante amplio que no se condice con el Ordenamiento jurídico chileno vigente.

${ }^{28}$ Resultan interesantes las reflexiones de MARTín PASTOR (2005) pp. 331-355, quien realiza una exposición bastante completa sobre el sometimiento al principio de legalidad y objetividad del MF español y de cuáles pueden ser los mejores medios de tutela de estas garantías.

${ }^{29}$ El art. 3 de la LOCMP adopta la fórmula del Código Procesal Penal Modelo para Iberoamérica, que define el principio de objetividad en los términos citados en su art. 69.

${ }^{30}$ Obsérvese que el principio de objetividad está consagrado en diversas legislaciones. Así en el Código Procesal Penal Modelo para Iberoamérica, en su art. 69; en la STPO alemana en su art. 160; en el CPP italiano en su art. 358 en relación con sus arts. 291 y 292 ter, y en la legislación española la objetividad se halla en el art. 7 del EOMF.

${ }^{31}$ Recuérdese que el acusador solo puede instar por la condena del culpable dentro de la legalidad penal, nunca fuera de ella. En Derecho español esto se desprende indubitadamente del art. 2 LECRIM y arts. 3.4, 6 y 7 EOMF.; Moreno Catena (1997) pp. 166-168; De la Oliva Santos (1999) pp. 191 y ss., y De la Oliva Santos (1992) pp. 9877-9884.
} 
Algún autor ${ }^{32}$ ha intentado justificar este tipo de prácticas en las distintas y legítimas interpretaciones que se pueden sostener sobre la aplicación de una u otra norma penal dentro de un ordenamiento. No desconocemos que la interpretación normativa en un ordenamiento jurídico complejo siempre importa una dosis de subjetividad inevitable, sin embargo, la norma penal debe ser el referente objetivo de las mismas. En este orden de ideas, creemos que lleva razón Roxin ${ }^{33}$ en el sentido que la interpretación de las normas penales está limitada por la literalidad de las mismas. La literalidad siempre vincula al intérprete en la medida que este no puede otorgarles un significado que rebase los sentidos posibles de ellas, puesto que de lo contrario se caería en la interpretación analógica penal. Es decir, la letra de las normas impone los límites de los sentidos posibles de las mismas, y solo dentro de estos, el intérprete puede dotar de contenidos precisos a las normas penales, para lo cual usará de los distintos elementos de interpretación ${ }^{34}$.

En consecuencia, tanto desde la perspectiva del principio de legalidad como del de objetividad deben ser rechazadas las prácticas de manipulación de hechos para hacerlos calzar con calificaciones incorrectas, o las prácticas de calificaciones degradadas incorrectas y de peticiones de atenuantes o de desistimientos de agravantes realizados en función de la confesión o no confesión del imputado, pues ello revela que el sostenimiento por el fiscal de un hecho punible o de otro, de una calificación u otra, o de una circunstancia modificatoria u otra, producidas en un mismo juicio, no dependen de la correcta aplicación de la norma penal, sino de un puro criterio de utilidad desde un punto de vista subjetivo del fiscal o institucional en el sentido de provocar

En Derecho italiano lo mismo se deduce del art. 112 Constitución italiana y arts. 50, 326, 358, 405 y 409 del CPPI. En doctrina se puede consultar a CALAMANDreI (1928) vol. V, pp. 15-17; PAOLI (1930) vol. VII, parte I, p. 67; SARACENO (1940) p. 217; ForTUNA (1993): pp. 48-49; FERRAJOLI (1995) pp. 734-737.

32 Riego Ramírez (2000) pp. 215-216, quien insinúa que el fiscal en la formulación de la acusación no se hallaría vinculado a la legalidad ni a la objetividad, puesto que ello dependería, entre otros factores, de la interpretación del Derecho aplicable.

33 ROXIN (1999) pp. 147-156. En un sentido idéntico MAURACH y ZIPf (1994) pp. 144-145, y JeSCHECK (1981) pp. 203-215. KAUFMANN (1976) pp. 81-103, quien señala que toda aplicación e interpretación de la ley importa un proceso de subsunción que contiene un razonamiento analógico (pero entendido como equivalente de interpretación teleológica) reconoce que dicha labor está limitada por la misma letra de la ley penal. En realidad para el autor alemán la subsunción es analógica en cuanto actividad dirigida a fijar la pertenencia (o no) de un supuesto concreto a un determinado tipo más o menos cerrado y preciso, para lo cual ha de atenderse a la naturaleza de la cosa (del caso) y si la naturaleza concreta de la cosa guarda correspondencia con el tipo penal. Dicha labor de subsunción (analógica o de interpretación teleológica) empero, no reconoce espacios para "voluntarismos interpretativos del juez" al margen del tipo legal. Dice KAUFMANN a este respecto: "la analogía encuentra su frontera en el derecho penal en el tipo de ilicitud que sirve de base al supuesto de hecho legal. Lo que queda más allá es investigación jurídica libre” p. 102.

${ }^{34}$ Entre muchos ejemplos de la jurisprudencia alemana, el autor ofrece el caso de la sustracción ilegítima de energía eléctrica, que no pudo ser castigado como hurto porque la energía eléctrica como concepto no se adecuaba al de cosa corporal en ninguno de sus sentidos posibles. Por esta razón en el año 1900 se tuvo que introducir el tipo de sustracción de energía eléctrica. ROXIN (1999) p. 151; MAURACH y ZIPF (1994) pp. 144 y ss. 
una confesión del imputado para obtener un juicio abreviado o reconocimiento de culpabilidad $^{35}$.

\section{PRINCIPIO Y GARANTÍA DE LEGALIDAD PENAL SUSTANTIVA Y LA PELIGROSA CREACIÓN DE UNA LEY PENAL SUSTANTIVA AD HOC}

El principio y garantía de legalidad penal se resume en dos aforismos latinos: nulla poena et nullum crimen sine lege y nulla poena sine crimine et sine culpa, los que significan que el juez se halla sometido a la ley, no pudiendo calificar como delitos "sino solo (y todos) los que, con independencia de sus valoraciones, vienen formalmente designados por la ley como presupuestos de una pena"36 y que el sometimiento del juez lo es a la ley en la medida que "las definiciones legislativas de las hipótesis de desviación vienen dotadas de referencias empíricas y fácticas precisas" 37 .

Solo a la ley está encomendada la tarea de determinar qué hechos precisos se consideran lo suficientemente lesivos como para describirlos como delitos y, por lo tanto, como presupuestos de una pena ${ }^{38}$. Esto quiere decir que a la norma legal corresponde establecer los hechos lesivos que se deben hallar previamente calificados de delitos, y de los cuales depende la pena.

Como se ve, la ley establece anticipadamente una coherente relación entre hecho lesivo, delito y pena atribuida. Esta imbricación de conceptos se vincula con la retribución penal en el sentido de que es la ley la que establece el nexo lógico entre delito y sanción, enlazando la proporcionalidad de la pena atendido el delito y, en último término, la proporcionalidad de la pena respecto del hecho ${ }^{39}, 40$.

Pues bien, todo esto se ve desbaratado con la introducción de las prácticas inadecuadas en el procedimiento abreviado o en el reconocimiento de culpabilidad (p. simpli-

35 La interpretación, aunque parezca una obviedad, busca esclarecer el acertado sentido de la norma penal, y no admite que a pretexto de interpretaciones más benignas para el acusado se pueda torcer el sentido correcto de la norma, pues con ello se estaría autorizando una especie de analogía bonam partem contra legem. Afortunamente la doctrina penal es clara a este respecto y lo declara expresamente. JESCHECK (1981) p. 208; MAURACH Y ZIPF (1994) pp. 144 y ss.

36 Ferrajoli (1995) p. 35

37 FERRAJOLI (1995) p. 35

38 Ferrajoli (1995) pp. 703-704. También MaUraCH y Zipf (1994) pp. 155-156.

39 Ferrajoli (1995) pp. 397-402. MAUraCH y Zipf (1994) pp. 155-156.

CABAÑAS GARCÍA (1991) pp. 290-295, anota que la debida proporcionalidad del hecho, el delito y la pena se rompe con las formulaciones de acusaciones sobre la base de hipótesis fácticas irreales. También LAFAVE E ISRAEL (1992) pp. 926 y ss.

40 En el Ordenamiento chileno es claro que el Derecho penal no resulta un buen ejemplo de proporcionalidad entre hecho, delito y pena. La incoherencia y desproporcionalidad en el tratamiento y castigo de las distintas figuras penales acaba siendo muy frecuente, fenómeno vinculado a una suerte de producción legislativa de emergencia tan propia de las sociedades latinoamericanas, en las cuales se responde punitivamente a graves y profundos problemas sociales.

Con todo, las prácticas criticadas vienen a agravar todavía más esa falta de rigor sistemático en la elaboración de las normas penales y que tienen por objeto asegurar la coherencia y proporcionalidad, pues a esa falta de aplicación de criterios dogmáticos cuidadosos por parte del legislador hay que añadir la producción arbitraria de normas penales generadas en el casuismo desbordado de la praxis procesal. 
ficado $)^{41}$. En efecto, la negociación penal que se ha producido mediante las prácticas del forzado ajuste de hechos a una calificación, o de las calificaciones inadecuadas al hecho, o de la petición de atenuantes o del abandono de agravantes en la modificación de la acusación suponen una grave infracción a la legalidad penal sustantiva.

Ya hemos visto en nuestro medio (de sobra conocido) cómo los jueces acogen manifiestas calificaciones inadecuadas a los hechos (incluidas las de las atenuantes y agravantes) condenando conforme a ellas, rompiéndose la relación del hecho lesivo, del delito y de la pena proporcionada establecida por la ley penal ${ }^{42}$. En el fondo, a través de estas prácticas se crean normas (leyes) penales ad $h o c^{43}$ aplicables al caso particular (¿igualdad ante la ley penal?), fruto de una acusación que se aparta de lo dispuesto en la ley, y que no responden a ningún criterio normativo fijado previamente (¿certeza de la ley penal?) ni mucho menos a una correcta sistemática dogmático penal ${ }^{44,}{ }^{45}$. Más bien suelen depender de criterios utilitaristas del fiscal y del MP y de la habilidad negociadora del imputado en cada caso, de modo que pueden existir dos hechos iguales y con iguales circunstancias, pero que se someten a normas penales ad hoc y consecuencias

${ }^{41}$ Resulta interesante constatar cómo esta cuestión que nosotros estamos criticando en el sistema chileno, a propósito de las malas prácticas del MP, ha sido reconocido en otros sistemas. De este modo, por ejemplo, el fenómeno tiene una identidad propia y reconocida en la justicia penal estadounidense. En este sistema se habla del law-making como una función del juez y que se justifica en los márgenes de discrecionalidad que este posee, de manera que la ley penal sustantiva legislada, general y abstracta, no es el único parámetro normativo del juez, el cual puede ser modificado con bastante amplitud por su mismo criterio de solución en el caso concreto. A este respecto, puede consultarse el trabajo de JESCHECK (1981) pp. 171 y ss.; y especialmente pp. 290-295; RODRÍGUEZ GARCÍA (1997) pp. 96-97. Una visión estadounidense de su sistema en LAFAVE E ISRAEL (1992) pp. 900 y ss., y especialmente 926-928.

42 Ferrajoli (1995) pp. 746-752.

43 Con este giro (ad hoc) queremos expresar la idea de que la norma penal en estos casos no viene fijada por la ley, sino por la misma actividad negociadora realizada por el fiscal, a través de las nocivas prácticas denunciadas. FERrAjoli (1995) pp. 749-752, incide en este punto. Dice que el acusador público usando y abusando de las posibilidades de negociación puede generar una modificación de Derecho penal sustantivo mediante la técnica de rebajas de penas.

Creemos que esa modificación de la ley penal sustantivas que se dan en las negociaciones penales, reviste varios problemas. En primer lugar, la ausencia de permanencia y estabilidad de la norma, ya que su validez normativa solo se extiende al caso particular, es decir, es una norma penal ad hoc, de modo que pueden haber dos casos particulares iguales con distintas normas penales. Una más grave que otra, lo cual dependerá en cada caso de la habilidad negociadora del acusador versus la del imputado y su defensa. En segundo lugar, como es evidente, la existencia de tantas normas penales como casos de negociación penal existan, sin obedecer a un criterio único, infringe el principio de igualdad y de seguridad jurídica, pilares básicos de los ordenamientos jurídicos dentro de un Estado democrático de Derecho.

Otro autor que ha puesto de manifiesto este fenómeno es FANCHIOTTI (1998) pp. 323-324, pero referido a los amplios márgenes de discrecionalidad de la acusación pública norteamericana en la determinación de la norma penal aplicable al caso concreto, pudiendo alterar las previsiones legales (law making). También Rodríguez GarCÍA (1997) pp. 95-109.

44 FANCHIOTTI (1998) pp. 314-327. Creemos que esta puede ser una de las principales críticas a la coherencia de un sistema discrecional como el estadounidense.

Conviene observar que MAURACH y ZIPF (1994) pp. 159-162, consideran que la prohibición de la analogía penal que impone el principio de legalidad se refiere también a la pena: nulla poena sine lege stricta, de la cual derivaría la prohibición de penas arbitrarias, como también la proscripción de creación de tipos por vía judicial. Consultar también a JESCHECK (1981) pp. 171 y ss., y especialmente pp. 173-174.

45 De la Oliva Santos (1992) pp. 9877-9884; y 131 y ss.; Martín PASTOR (2005) pp. 350-352. 
penales concretas notablemente distintas ${ }^{46,47}$. El resultado normativo y punitivo podrá depender de múltiples factores extralegales y extradogmáticos. Por ejemplo, de cuán recargado de trabajo esté el fiscal que lleve el caso, pues dependiendo de ello este podrá ser más proclive a ofrecer una "buena calificación y rebaja" para "sacarse de encima" el juicio oral. En cambio si toca un fiscal más desahogado de trabajo o más eficiente disminuyen las posibilidades de que ofrezca una "buena calificación y rebaja" a cambio de la aceptación de hechos (confesión). También puede depender de la habilidad negociadora del imputado y del asesoramiento de la defensa, que por ejemplo ante una acusación inicial "intimidatoria" y "agravada” mantenga la tranquilidad y se espere a una buena rebaja penal en la modificación de la acusación y que solo ante esa rebaja esté dispuesta a aceptar los hechos.

La cuestión de que a hechos iguales y con iguales circunstancias se les pueda someter a normas penales diversas, dependiendo de la confesión -al que confiesa, la ley penal negociada ad hoc; al que no confiesa, la ley estricta- y de ahí hacer derivar consecuencias penales concretas diametralmente opuestas, implica que en el sistema de negociación (no regulado) en el que a menudo se convierte el procedimiento abreviado o el reconocimiento de responsabilidad se infrinjan aspectos de la legalidad penal que estimamos fundamentales: la certeza de la ley penal o la prohibición de leyes penales y penas indeterminadas, y la igualdad ante las mismas ${ }^{48}$.

Estas infracciones se producen como resultado de una intencionada interpretación incorrecta de las normas penales por parte del MP, práctica necesaria para dar lugar a las calificaciones de delitos degradados que no se corresponden con el hecho punible, o para hacer aparecer atenuantes inexistentes o hacer desaparecer claras agravantes ${ }^{49}$.

Justo en este punto es oportuno aclarar una duda que puede surgir, referida al carácter del principio de legalidad. Según se sabe, tradicionalmente ha sido considerado

46 Ferrajoli (2004) pp. 45 y ss., con relación al carácter universal de los derechos fundamentales, dice que una característica muy señalada de ellos es su universalidad, es decir, que su titularidad corresponde a todos y que su goce ha de ser en la misma medida. No son susceptibles de cuantificación, en consecuencia, cabe concluir que si somos titulares del derecho a la presunción de inocencia, del derecho a juicio, de la garantía de la reserva de legalidad penal, todas ellas pertenecen a todos y en la misma medida. No cabe tener más derecho a la presunción de inocencia que otro individuo, como tampoco tener solo a veces o en determinados casos derecho a juicio y en otros casos no, como tampoco cabe tener solo a veces derecho a la reserva legal en materia penal.

47 TARUFFo (2005) pp. 37 y ss., ha señalado que el desprecio ideológico por el establecimiento de la verdad de los hechos en el proceso está íntimamente vinculado con las ideologías eficientistas del proceso, que ven en él un instrumento para la resolución de conflictos, sin ninguna referencia a la justa decisión del mismo, como podría ser la correcta aplicación de la norma legal. Dice críticamente Taruffo que, para las ideologías eficientistas del proceso "una resolución puede ser buena aunque la decisión se funde sobre una determinación falsa, inaceptable o parcial de los hechos del caso, siempre que sea capaz de resolver la controversia”, p. 39. También ORLANDI (2003) pp. 554 y ss.

48 Con relación a las prácticas negociadoras en el sistema estadounidense se han formulado críticas de semejante naturaleza. LAFAVE e ISRAEL (1992) pp. 900-928; PIZZI (2004) pp. 102-104 y 207-216; RODRÍGUEZ GARCÍA (1997) pp. 96-97.

49 Roxin (1999) pp.147-156, quien pone en evidencia la relación que existe entre correcta interpretación y el principio de legalidad, y la prohibición de analogía que de este se desprende. También JESCHECK (1981) pp. 203-215. 
como una garantía del imputado ante el poder punitivo del Estado, y por esta razón ha operado como prohibición en el sentido de que el Estado-juez no puede condenar por analogía cuando el hecho no está precisamente descrito en la ley, ni puede condenar por un delito o pena más grave que la dispuesta por la ley ${ }^{50}$. Este ha sido el significado que se ha puesto de relieve tradicionalmente, pues eran las hipótesis de castigo de hechos no tipificados en la ley, o de castigo más grave que el que la ley disponía, las situaciones que solían darse en la experiencia del proceso penal. ¿De lo anterior se desprendería entonces que las prácticas denunciadas al suponer siempre una atenuación del poder punitivo no infringirían las garantías que hay tras la vigencia del principio de legalidad?

En efecto, todas las prácticas analizadas y criticadas implican en principio una atenuación del poder punitivo, de tal modo que inicialmente podría pensarse (equivocadamente) que no son un ataque directo a la vigencia de la legalidad en el sentido de garantía. Sin embargo, esto no es más que un espejismo, puesto que dichas prácticas, como hemos demostrado, no persiguen el trato más favorable del imputado a través de la renuncia a perseguir toda la consecuencia punitiva consagrada en la ley, sino todo lo contrario, su fin es el aseguramiento de un castigo sin juicio, cualquiera sea la sanción y aun cuando sea apartándose de la ley penal, de manera que su propósito siempre será represivo o punitivo; nunca de garantía para el imputado51. De no ser así, entonces cómo se explica que estas ventajas o rebajas penales no se otorguen si no es a cambio de la confesión.

Por lo demás, la legalidad penal si bien tiene un contenido de garantía, también implica un mandato ineludible en orden a que se debe aplicar la norma sancionada en la ley, y no otra. La ley penal no opera solamente como un techo o tope máximo, dejando hacia abajo amplios márgenes de discrecionalidad para el acusador y para el juzgador, como áreas para crear normas penales atenuadas aplicables a casos particulares. Por el

50 Estas son las prohibiciones como consecuencias de la legalidad dirigidas al Estado-juez, pero también existen otras dos prohibiciones que van dirigidas al Estado-legislador, que son la prohibición de la retroactividad de la ley penal y la prohibición de leyes penales y penas indeterminadas. RoXIN (1999) pp. 140175.

${ }^{51}$ Ha dado la misma explicación Rodríguez GARCía (1997) pp. 93-109.

Se reconoce esta cuestión incluso por PIZZI (2004) pp. 102-104 y 207-216, quien dice que el sistema que se basa en la negociación extraprocesal acaba fomentando los acuerdos de castigos penales conseguidos de cualquier manera y sin importar su contenido. El sistema criminal estadounidense llega a reconocer que esto es así e intenta "solucionar" el manifiesto divorcio entre la realidad procesal y el pacto incriminatorio, a través de mecanismos como el que explica PIZZI, de que los jueces federales deban "determinar la sentencia [pena] a imponer no solo en base al delito por el que se condenó al acusado o en base al delito cuya comisión admitió, sino también teniendo en consideración 'el delito o delitos efectivamente cometidos', lo cual se determina mediante una investigación extraprocesal que lleva a cabo un funcionario encargado de las libertades condicionales, normalmente recurriendo a los archivos del FBI y otros organismos. Esto significa que si el acusado admitió su culpa con respecto a un robo en un banco, pero el Juez llega a la conclusión de que cometió tres, la sentencia deberá ser agravada en base a que el acusado cometió efectivamente ese número de robos", p. 103.

Es evidente que un sistema de este tipo no es admisible en un Ordenamiento que asegura la eficacia normativa de las garantías del Derecho penal y procesal. Con ello se revela que los sistemas de negociación extraprocesal están previstos en los Ordenamientos para facilitar la aplicación del ius puniendi y por lo tanto siempre son sustancialmente represivos. 
contrario, la norma de la ley penal es la única que se puede aplicar, dentro de sus máximos y sus mínimos sancionados. Lo demás es discrecionalidad al margen de la ley, que será inadmisible si no hay una norma legal -y constitucional- que la admita y la regule ${ }^{52}$.

\section{LA VIGENCIA DE IMPORTANTES GARANTÍAS PROCESALES PENALES, ESPECIALMENTE LA PRESUNCIÓN DE INOCENCIA Y LA GARANTÍA JURISDICCIONAL}

En un proceso penal con vigencia de garantías procesales, e informado por la presunción de inocencia, la declaración del imputado es el principal medio de defensa para poder refutar la acusación, y no un medio de autoinculpación. En estricto rigor debiera prohibirse legalmente cualquier uso autoinculpatorio de la declaración (confesión) del imputado ${ }^{53}$.

La vigencia de la presunción de inocencia se manifiesta en dos consecuencias o requisitos respecto de la prueba y que inciden en el juicio fáctico de la sentencia. De una parte, se refiere a los requisitos bajos los cuales puede el juez formar su convicción de culpabilidad y, de otra, se vincula con el régimen que regula las consecuencias de la incertidumbre o falta de convicción acerca de los elementos fácticos que conforman el hecho delictivo o la participación culpable.

La ley establece primero bajo qué presupuestos de prueba el juez puede formar su convicción de culpabilidad, para luego regular en este contexto el resultado de no convicción o de incertidumbre sobre algún hecho referido a la culpabilidad, en concordancia con la vigencia del principio de inocencia.

A nosotros nos interesa la primera cuestión y que estriba en la necesidad de que en el proceso (el juicio) exista prueba que se haya practicado con todas las garantías y que sea objetivamente incriminatoria. En este sentido la convicción de culpabilidad no se puede sostener si no es en esta prueba ${ }^{54}$, lo cual quiere decir que no basta con que en el proceso exista prueba sin más (una mínima actividad probatoria), para que a continuación el juzgador se halle autorizado a formar su convicción de culpabilidad libremente, sino que se exige además que esa convicción se base en una prueba que, habiéndose introducido al proceso con todas las garantías, sea objetivamente incriminatoria. Esto es, que la prueba contenga una información positiva que de ser valorada como cierta por el juez dé lugar al establecimiento de un hecho determinante de la responsabilidad criminal o constitutivo de un indicio.

El imperativo de este carácter de la prueba se conoce también como la exigencia de efectiva prueba de cargo, y significa que el juzgador podrá fundar su convicción de

\footnotetext{
52 La doctrina penal ha aclarado este punto con bastante rotundidad. Primero ha dicho que la interpretación busca el sentido correcto de la norma, y no puede aceptarse que a pretexto de trato más favorable al acusado se hagan interpretaciones incorrectas, y segundo, ha establecido que el juez no puede crear normas penales. En este sentido, entre otros, nada menos que JESCHECK (1981) p. 208; MAURACH y ZIPF (1994) pp. $144-145$ y 164 .

53 FerRAJOli (1995) p. 608. Una visión especialmente completa y con variados matices acerca de la intervención del imputado en la reconstrucción del hecho se puede hallar en BUZZELLI (1992) pp. 79-108. ${ }^{54}$ Vegas Torres (1993) pp. 35-181.
} 
culpabilidad solo cuando en el proceso exista prueba de la que se desprenda objetivamente un hecho "que pueda considerarse directamente determinante de la responsabilidad criminal del acusado o, cuando menos, constitutivo de un indicio de dicha responsabilidad" 55 .

La concepción descrita está latente en el CPP, pues el art. 98 considera a la declaración del imputado como un medio de defensa de este, de manera que en principio la ley parece privarle de efecto autoincriminatorio a la declaración del imputado. No obstante, el art. 340 inciso $3^{\circ}$ matiza la afirmación precedente al establecer que "No se podrá condenar a una persona con el solo mérito de su propia declaración”, con lo cual se viene a señalar que no se puede fundar la sentencia de condena exclusivamente en la confesión, pero a la vez no prohíbe su utilización inculpadora, sino al contrario, la reconoce, aunque condicionada a la existencia de otras pruebas ${ }^{56,57}$.

El legislador chileno establece en el CPP un sistema en el que se exige prueba de cargo, y que considera, además, como legalmente insuficiente a la autoincriminación, expresada en la garantía de que nadie puede ser condenado con el solo mérito de su propia declaración (art. 340 inciso $3^{\circ}$ ), con lo cual se impone al acusador la carga (formal) de aportar pruebas ${ }^{58}$ inculpadoras distintas de la "confesión" del imputado ${ }^{59}$.

En la regulación del procedimiento abreviado existe una norma en el mismo sentido, es decir, que dispone la insuficiencia de la confesión para condenar. Así, requiere además de otros antecedentes, de manera que la aceptación de hechos (la confesión) se ha de hacer sobre la base de unos antecedentes inculpadores recabados en la investigación y que sirven de base a la acusación (art. 406). Y por esa misma razón se prohíbe que la sentencia condenatoria del juicio abreviado se funde únicamente en la aceptación de hechos (art. 412).

\footnotetext{
55 VEGAS TORRES (1993) pp. 130-131.

56 Esta norma consagra en el CPP chileno la doctrina de la "mínima actividad probatoria con contenido objetivamente incriminatorio”. Es evidente la influencia de la doctrina española en este punto, como lo ha reconocido el propio legislador chileno. Pfeffer URQUiaga (2001) p. 399.

57 Reconocemos que el mismo Ferrajoli (1995) pp. 606-612, admite el uso de la declaración con efecto autoinculpatorio, pero sujeto a la condición de la existencia de otras pruebas inculpadoras. Nuevamente BUZZELLI (1992) pp. 79-108.

58 Cabe recordar nuevamente que en el sistema chileno es posible usar la expresión carga formal de la prueba en el caso del acusador, pues en el nuevo proceso penal chileno el juez o tribunal no tiene poder alguno para intervenir en la introducción de fuentes de prueba o para ordenar la práctica de prueba de oficio, de modo que se puede hablar en estricto rigor que es a la acusación pública y privada a quienes incumbe aportar la prueba de cargo para poder probar su acusación. Esta afirmación no podría sostenerse para otros sistemas como el español o el italiano. VEGAS TORRES (1993) pp. 204-205; OrTELLS RAMOS (1998) pp. 283-287; CHIAVARIO (1982) pp. 148-149.

59 El criterio rector en esta materia tiene que ser la existencia de "antecedentes o elementos" claros y directamente inculpatorios, además de autónomos e independientes de la confesión o aceptación de participación, puesto que de otro modo se estaría legitimando una sentencia condenatoria sin juicio y fundada exclusiva o principalmente sobre la base de la confesión, lo cual rompería con el principio jurídico de que la declaración del imputado es un derecho o medio de defensa (art. 98 del CPP) y que, por tal motivo, la confesión no debe admitirse como único elemento incriminador, como lo sanciona el art. 340 inciso $3^{\circ}$ para el proceso ordinario, norma que se aplica al procedimiento simplificado supletoriamente al no estar este principio expresamente previsto en sus artículos específicos.
} 
La confesión del procedimiento abreviado tiene, sin embargo, una peculiaridad importante respecto de la que se puede producir en el proceso ordinario, consistente en que ella misma es presupuesto del juicio abreviado y que de ella depende el valor probatorio incriminador de lo que naturalmente no es prueba, como son los antecedentes de la investigación en que se funda la acusación. De consiguiente, en estricto rigor la sentencia de condena -aunque la ley no se atreva a decirlo- se basa realmente en la confesión, aunque acompañada de los antecedentes de la investigación que valen como prueba de incriminación gracias a la previa confesión, y no a su valor intrínseco de prueba que por cierto no posee.

Esto que todavía se puede tolerar con el fin de no echar por tierra las previsiones normativas del legislador, en orden a contar con procesos alternativos que sirvan de sistema de racionalización de medios, nos parece francamente inaceptable cuando se convierte en un mecanismo de provocación de confesiones a través de las prácticas de ofrecimiento de "ventajas o premios" punitivos al margen de la ley penal.

La forma de "justicia penal" que se basa en la obtención a toda costa de confesiones no solo persigue optimizar el uso de medios y la celeridad (como habitualmente se argumenta), sino también pretende exonerar al acusador de la carga (formal) de la prueba de la acusación (como fin instrumental); la negociación a través de las prácticas que hemos denunciado buscan evitar o eludir la carga de la prueba que recae en el acusador en el juicio penal, nulla accusatio sine probatione $e^{60}$, y lograr imponer una pena -cualquiera sea esta- sin juicio (completo) en el cual se pruebe la acusación. Cabe preguntarse en consecuencia, ¿dónde queda la presunción de inocencia hasta prueba en contrario, sobre todo cuando las confesiones son provocadas y conseguidas a cambio de ofrecimientos punitivos ilegales?

Aparte de la anterior, hay una segunda garantía procesal quebrantada a través de las prácticas denunciadas. Nos referimos a aquella denominada como jurisdiccional. La aplicación del Derecho penal se rige por la garantía jurisdiccional, consistente en que el Derecho penal no se puede aplicar si no es mediante el proceso jurisdiccional. Es decir, la única forma de aplicación de la ley penal es mediante el proceso sustanciado por el juez establecido por la ley, de modo que no puede haber una pena sin una previa acusación, la cual debe ser enjuiciada en un proceso jurisdiccional ${ }^{61}$.

60 Ferrajoli (1995) pp. 610-613. Este autor explica el sentido de carga de la prueba de la acusación con toda claridad, cuando dice: "Al estar la inocencia asistida por el postulado de su presunción hasta prueba en contrario, esta prueba contraria debe aportarla quien niega aquélla formulando la acusación. De aquí el corolario de la carga acusatoria de la prueba expresado por nuestro axioma...nulla accusatio sine probatione”, p. 611. También Montero Aroca (1997) pp. 153-156, pp. 35-36; Rodríguez García (1997) pp. 100 y ss.

${ }^{61}$ Montero Aroca (1997) pp. 15-21; Ferrajoli (1995) precisamente, pp. 33-116 y 537-603, aunque a lo largo de toda la obra subyace la idea de que el garantismo penal descansa en la garantía jurisdiccional. Sin ella se diluyen las demás garantías procesales y sustanciales o de Derecho material.

Cabe poner de relieve la crítica que se ha hecho en este sentido a sistemas de negociación penal como el estadounidense. ILLUMinATi (1988) p. 4, no duda en calificar al sistema de negociación penal estadounidense (que es la forma general de aplicación de la Ley penal en ese país) como un sistema de aplicación de la Ley penal de carácter burocrático-administrativo, el cual en definitiva toma el lugar del sistema jurisdiccional y acusatorio teóricamente consagrado. 
La garantía jurisdiccional en Derecho chileno está prevista en el art. 1 inciso $1^{\circ}$ CPP, que dispone: "Ninguna persona podrá ser condenada o penada, ni sometida a una de las medidas de seguridad establecidas en este Código, sino en virtud de una sentencia fundada, dictada por un tribunal imparcial”.

Cuando nos hallamos frente a situaciones en que se persigue "forzar" al juez a que condene por un hecho consensuado por las partes con independencia de su correspondencia o no correspondencia con los antecedentes probatorios de la causa y por una calificación jurídica que muy frecuentemente no suele ser la técnicamente adecuada al hecho y a la ley penal, nos encontramos frente a una situación de crisis de la garantía indicada, ¡qué duda cabe! La jurisdiccionalidad en la aplicación del Derecho penal debe suponer un verdadero enjuiciamiento jurisdiccional, de modo que la "sentencia" que se limita a recoger una acusación aceptada por el acusado no es en sentido estricto sentencia jurisdiccional y, por lo tanto, no satisface la garantía enunciada ${ }^{62}$.

\section{LAS POTESTADES JURISDICCIONALES CORRESPONDEN EXCLUSIVAMENTE A LOS JUECES}

Estas prácticas vulneran las potestades jurisdiccionales, ya que la calificación inadecuada al hecho, o el forzamiento del hecho para hacer una calificación improcedente, o la petición de atenuantes o el desistimiento de agravantes, que constituyen un evidente apartamiento de la ley con el propósito de hacer una rebaja de la petición de pena que objetivamente no procede, en la práctica limita los poderes de calificación o de aplicación del Derecho del juzgador y de enjuiciamiento fáctico. En efecto, el juez formalmente mantiene intactos sus poderes de calificación y de enjuiciamiento fáctico en el procedimiento abreviado y en el reconocimiento de culpabilidad, con lo cual podría enjuiciar y calificar el hecho punible y sus circunstancias (modificatorias) conforme a su criterio y convicción, empero la realidad es que se verá limitado por el margen punitivo máximo de la acusación, que manipulado a través de las prácticas denunciadas, muchas veces ni siquiera coincidirá con el mínimo punitivo del delito y sus circunstancias por el que podría calificar el juzgador.

De este modo, si bien podría desestimar la calificación del fiscal por una más grave, o desestimar la petición de una atenuante o estimar que sí concurre una agravante "desistida" por el fiscal, dichas calificaciones quedarán en la práctica carentes de consecuencias jurídicas, imponiéndose sobre estos extremos la acusación. El juzgador se verá en la situación de tener que condenar por una pena rebajada, hasta el extremo de tener que poner una pena que no se corresponda ni siquiera con el mínimo previsto por la ley penal para el delito y sus circunstancias, conforme la calificación que correspondía hacer en la sentencia.

\footnotetext{
${ }^{62}$ Las observaciones que hace sobre estas materias GASCÓN ABELLÁN (1999) pp. 125 y ss. Son oportunas también las reflexiones de COMANDUCI (1992) pp. 215-244, en el sentido de vincular la motivación fáctica de la sentencia a la misma garantía jurisdiccional. La jurisdicción importa en sí misma la primera garantía en la aplicación del Derecho, entre otras razones, porque implica una forma de aplicación de la norma jurídica justificada y razonada, en último término, debidamente motivada.
} 
Como ejemplo de lo que decimos, recordemos el caso de la SJG de Villarrica, de 7 de agosto de 2001, rol interno 193-2001, en que la calificación correcta a todas luces era la de robo con intimidación en grado de frustrado (que en Chile se castiga como consumado, art. 450 del CP), con una pena legal de presidio mayor en su grado mínimo a presidio mayor en su grado máximo, es decir, desde 5 años y 1 día a 20 años. Sin embargo, el fiscal calificó (intencionalmente mal) como amenazas condicionales, cuya pena es de presidio menor en su grado medio a presidio menor en su grado máximo, esto es, desde 541 días a 5 años, pidiendo concretamente el mínimo de 541 días de presidio. En este caso ni la pena abstracta de las amenazas ni la concreta pedida por el fiscal llega a la pena mínima prevista para el delito de robo con intimidación que realmente acaeció.

Lo mismo acontece en el caso de la SJG de Temuco, de 23 de octubre de 2001, rol interno 1168-2001, en el cual se calificó como delito de receptación unos hechos que encajan perfectamente en un delito de robo con fuerza en lugar no habitado. Las penas pedidas (para varios imputados) son de presidio menor en su grado mínimo, en tanto que el delito de robo con fuerza en lugar no habitado tiene asignada una pena de presidio menor en su grado medio a máximo. En esta causa nuevamente la pena pedida ni siquiera llega al mínimo de pena del delito que realmente existió.

Una situación análoga se produjo en el caso de la SJG de Santiago (15\%), de 10 de mayo de 2007, rit 4235-2006, en el cual el verdadero delito acaecido era el de robo con fuerza en lugar habitado, cuyo rango de pena no solo impedía la aplicación del procedimiento abreviado, sino que además (dicho rango) en su parte inferior era mayor que la máxima aplicable al robo en lugar no habitado.

En estas causas el juzgador condenó conforme a la acusación, pero de haber calificado de conformidad a la ley penal, ejerciendo sus potestades jurisdiccionales, se habría encontrado ante la paradoja de no poder imponer la consecuencia penal que de ella se deriva, sino la que pide el fiscal, lo cual demuestra que en la práctica se termina imponiendo la calificación del MP. Esta situación generada por las prácticas denunciadas constituye una expresa contravención de la norma constitucional del art. 76, que dice que la potestad jurisdiccional radica exclusivamente en los tribunales de justicia, y de la norma constitucional del art. 83, que prohíbe al MP ejercer funciones jurisdiccionales (y del art. 1 de la LOCMP que repite la norma constitucional) ${ }^{63}$.

Por todas las razones jurídicas dadas precedentemente es que advertíamos en la introducción de este trabajo que no es posible concebir el acto de consenso en el proceso penal como si fuera un acto de causación ${ }^{64}$, que venga a determinar el contenido de la sentencia (ya que dejaría de ser sentencia jurisdiccional), ni muchos de que ello acontezca por vías de hecho no reguladas ni previstas en el sistema procesal penal.

\footnotetext{
63 Conviene tener presente la observación que realiza PIZZI (2004) pp. 212-213, quien afirma que en un sistema de negociación extraprocesal se termina confiriendo la potestad de enjuiciamiento penal al fiscal y no al órgano jurisdiccional.

64 Goldschmidt (1935) p. 63, y también AlCalá-Zamora y Castillo (1962) pp. 118-119; De Diego DÍEz (1997) pp. 138-139.
} 


\section{BIBLIOGRAFÍA CITADA}

AlCAlÁ-Zamora y CASTillo, Niceto (1962): El allanamiento en el proceso penal (Buenos Aires, EJEA) 293 pp.

Bustos Ramírez, Juan (1994): Manual de Derecho penal (Barcelona, PPU, cuarta edición) $614 \mathrm{pp}$.

BuZzELl, Silvia (1992): "Il contributo dell'imputato alla recostruzione del fatto", en: VV.AA., La conoscenza del fatto nel processo penale, a cura di Giulio Ubertis (Milano, Giuffrè).

Cabezudo Rodríguez, Nicolás (1996): El Ministerio Público y la justicia negociada en los Estados Unidos de Norteamérica (Granda, Comares) 340 pp.

Calamandrei, Piero (1928): "Il concetto di 'lite' nel pensiero di Francesco Carnelutti”, Rivista Diritto processuale civile, vol. V.

CHAHUÁN SARRÁS, Sabas (2002): Manual del nuevo procedimiento penal (Santiago, Lexis Nexis) 330 pp.

ChIVArio, Mario (1982): Processo e garanzie della persona (Milano, Giuffrè) volume II.

Comanduci, Paolo (1992): "La motivazione in fatto", en: VV.AA. La conoscenza del fatto nel processo penale, a cura di Giulio Ubertis (Milano, Giuffrè)

De Diego Díez, Luis-Alfredo (1997): La conformidad del acusado (Valencia, Tirant lo Blanch) $582 \mathrm{pp}$.

De la Oliva Santos, Andrés (1992): "Disponibilidad del objeto, conformidad del imputado y vinculación del tribunal a las pretensiones en el proceso penal”, Revista General del Derecho, vol. octubre-noviembre.

De la Oliva SANTOS, Andrés (1999): Derecho procesal penal (Madrid, ECERA, cuarta edición) $935 \mathrm{pp}$.

Del Río FERRETTI, Carlos (2006): El deber de correlación de la sentencia con la acusación y la defensa. Estudio comparado del Derecho español con el chileno (Universidad de Valencia, tesis doctoral inédita).

FANCHIOTTI, Vittorio (1998): "Riflessioni sulla giustizia penale in U.S.A.”, Cassazione penale, fascicolo 1.

Ferrajoli, Luigi (1995): Derecho y razón. Teoría del garantismo penal (Madrid, Trotta) $991 \mathrm{pp}$.

FERrajoli, Luigi (2004): Derechos y garantías. La ley del más débil (Madrid, Trotta) 180 Pp.

ForTuna, Ennio (1993): Manuale pratico del nuovo processo penale (Padova, Cedam) $1.171 \mathrm{pp}$.

GASCÓn Abellán, Marina (1999): Los hechos en el Derecho. Bases argumentales de la prueba (Madrid-Barcelona Marcial Pons) $230 \mathrm{pp}$.

Gimeno Sendra, Vicente (1997): Derecho procesal penal (Madrid, Colex) 942 pp.

GoldSCHMidT, James (1935): Problemas juridicos y políticos del proceso penal (Barcelona, Bosch) 128 pp.

Heumann, Milton (1978): Plea Bargaining (Chicago and London, The University of Chicago Press) 220 pp. 
Horvitz Lennon, María (2002): Derecho procesal penal chileno (Santiago, Editorial Jurídica de Chile) tomo I, 638 pp.

IlluminATI, Giulio (1988) "Accusatorio ed inquisitorio (sistema)", Enciclopedia Giuridica (Istituto della enciclopedia italiana, Roma) tomo I.

Jescheck, Hans Heinrich (1981): Tratado de Derecho penal. Parte general (Barcelona, Bosch) volumen I, 913 pp.

Kaufmann, Arthur (1976): Analogía y naturaleza de la cosa. Hacia una teoría de la comprensión jurídica (Santiago, Editorial Jurídica de Chile) 109 pp.

LAFAVE, Wayne e ISRAEL, Jerold (1992): Criminal procedure (St. Paul, West Publishing) 813 pp.

MARTÍn PASTOR, José (2005): El Ministerio Fiscal como director de la investigación oficial en el proceso penal (Bolonia, Real Colegio de España) 450 pp.

Maurach, Reinhart y Zipf, Heinz (1994): Derecho penal. Parte general (Buenos Aires, Astrea).

Montero Aroca, Juan (1997): Principios del proceso penal, una explicación basada en la razón (Valencia, Tirant lo Blanch) $191 \mathrm{pp}$.

Moreno Catena, Víctor (1997): Derecho procesal penal (Madrid, Colex) 942 pp.

Orlandi, Renzo (2003): "Procedimenti speciali", en: VV.AA. Compendio di procedura penale (Padova, Cedam, Segunda edición)

Pfeffer Urquiaga, Emilio (2001): Código procesal penal anotado y concordado (Santiago, Editorial Jurídica de Chile) 828 pp.

PIZZI, William (2004): Juicios y mentiras. Crónica de la crisis del sistema procesal penal estadounidense (Madrid, Tecnos) $261 \mathrm{pp}$.

RodrígueZ GARCÍA, Nicolás (1997): La justicia penal negociada. Experiencias de Derecho comparado (Salamanca, Ediciones Universidad de Salamanca) 343 pp.

Roxin, Claus (1999): Derecho penal, Parte general (Civitas, Madrid) tomo I.

Roxin, Claus (2000): Derecho procesal penal (Buenos Aires, Editores del Puerto) 601 pp.

SARACENO, Pasquale (1940): La decisione sul fatto incerto nel processo penale (Cedam, Padova)

SCHÜNEMANN, Bernd (2005): La reforma del proceso penal (Madrid, Dykinson) 112 pp.

TARUfFO, Michele (2005): La prueba de los hechos (Madrid, Trotta) 542 pp.

Vegas TORRes, Jaime (1993): Presunción de inocencia y prueba en el proceso penal (Madrid, La Ley) 414 pp.

Vives Antón, Tomás (1999): Derecho penal, parte general (Valencia, Tirant lo Blanch) 998 pp.

Zipf, Heinz y Maurach, Reinhart (1994): Derecho penal. Parte general (Buenos Aires, Astrea).

\section{JURISPRUDENCIA CITADA}

SJG de Loncoche, de 11 de septiembre de 2001, RIT 77-2001.

SJG de Taltal, de 23 de febrero de 2002, RIT 75-2001.

SJM de Taltal, de 23 de marzo de 2002, RIT 109-2002. 
Del Río Ferretti, Carlos "El principio del consenso de las partes en el proceso penal..."

SJG de Loncoche, de 22 de abril de 2002, RIT 764-2001.

SJG de Temuco, de 18 de junio de 2002, RIT 3615-2001.

SJG de Linares, de 23 de febrero de 2003, RIT 1845-2002.

SJG de Santiago (15), de 10 de mayo de 2007, RIT 4235-2006. 